\title{
Germination of faba beans (Vicia faba L.) for organic weaning piglets
}

\author{
P. Schwediauer • W. Hagmüller • W. Zollitsch
}

Received: 30 May 2017 / Accepted: 4 September 2017 /Published online: 16 September 2017

(C) The Author(s) 2017. This article is an open access publication

\begin{abstract}
Faba beans (Vicia faba L.) contain antinutritive compounds that can reduce digestibility and palatability. Germination has been reported to reduce some of those components. The effect of including germinated faba beans in their feed was tested on 160 weaner pigs that were assigned to one of four diets containing either $19 \%$ peas (RP19), $16 \%$ raw faba beans (RFB16), 16\% germinated faba beans (GFB16) or 24\% germinated faba beans (GFB24). Crude protein was slightly higher in germinated as compared to raw beans. Most of the essential amino acids decreased due to germination, their contents relative to lysine remained the same. There were no significant differences in live weight on days 8,15 and 22. At the end of the trial (day 29), live weight of GFB24 was significantly reduced when compared to RP19 and RFB16, but not to GFB16. In week 4, daily weight gain of GFB24 was significantly lower than of all other treatments. There were no significant differences in feed intake between the treatments. It was possible to feed germinated faba bean in amounts up to $240 \mathrm{~g} \mathrm{~kg} \mathrm{FM}^{-1}$ without a reduction in feed intake or a higher incidence of diarrhoea, although live weight
\end{abstract}

P. Schwediauer - W. Zollitsch

Department of Sustainable Agricultural Systems, Division of Livestock Sciences, BOKU_-University of Natural Resources and Life Sciences Vienna, Gregor Mendel Strasse 33, 1180 Vienna, Austria

W. Hagmüller $(\bowtie)$

Austrian Research and Education Center, Institute of Organic Farming and Farm Animal Biodiversity, Austraße 10, 4600 Thalheim/Wels, Austria e-mail: werner.hagmueller@ raumberg-gumpenstein.at and daily weight gain were reduced. Under the circumstances of this study and considering the effort related to the process, germination cannot be recommended as a method to improve the nutritive value and acceptance of faba beans for feeding of weaner pigs.

Keywords Grain legumes · Germination · Sprouts · Organic farming $\cdot$ Feeding

\section{Introduction}

The European demand for organic feedstuffs rich in high-quality protein, necessary for the formulation of diets that allow for an efficient production of lean pigs, exceeds the availability. This results in a dependency on imports, mainly of expensive soybeans and soybean cake (Zollitsch 2007; Früh et al. 2015).

Faba bean (Vicia faba L.) is a domestic crop rich in protein, but contains so-called anti-nutritional factors (ANF). These secondary plant metabolites reduce the nutritive value of faba beans and constrain their use as a feedstuff (Crépon et al. 2010). Additionally, structural properties of the storage protein of faba beans itself could limit their digestibility (Carbonaro et al. 2000, 2014). Usual recommendations for inclusion of faba beans in rations for weaner pigs range from $5 \%$ in conventional to 10-20\% in organic systems (Zollitsch et al. 2002; Blair 2007; Jeroch et al. 2008). If the content of ANF can be decreased, it is possible to feed amounts exceeding these recommended limits (Zijlstra et al. 2008; Emiola and Gous 2011). 
In human nutrition, germination is a common and traditional method for enhancing the nutritional value and palatability of grain legumes (Kaukovirta-Norja et al. 2004; Chaudhary et al. 2015). It is known to increase contents and availability of dietary minerals, protein and monosaccharides (Fernandez and Berry 1989; Frias et al. 2005) and to decrease ANF (Gulewicz et al. 2014).

The most relevant ANF in faba beans are tannins and $\alpha$-galactosides of the raffinose family oligosaccharides (RFO) (Makkar et al. 1997; Rubio 2007). RFO can promote bloating due to fermentation in the colon and increase the risk of diarrhoea because of a shift in the osmotic gradient (Dersjant-li and Peisker 2010). Tannins can reduce the digestibility of protein and the nutritional value of dietary energy (Crépon et al. 2010; Sarwar Gilani et al. 2012).

In faba beans, condensed tannins were significantly reduced after 24 and $72 \mathrm{~h}$ of germination (Alonso et al. 2000). RFO (raffinose, stachyose, verbascose, ajugose), which accounted for up to $50 \%$ of sugars in ungerminated faba bean, were markedly reduced after the second day of germination (Goyoaga et al. 2011). When feeding germinated legumes to rats, increased utilisation of protein was attributed to a decrease in contents of RFO (Donangelo et al. 1995).

The amino acid (AA) profile of faba beans is low in methionine and cysteine when compared to soybean. During germination storage, proteins are hydrolysed and the share of polypeptides, peptides and free amino acids increases (Urbano et al. 2005a, b). Those are potentially used for the synthesis of new compounds (Boulter and Barber 1963), which can be assembled from other amino acids than the former storage proteins and therefore alter the pattern of amino acids in germinated seeds (Peer and Leeson 1985; Ahmed et al. 1995). A general prediction of the effects of germination is difficult, as the outcome seems to depend on the species and variety studied, as well as the technical parameters of germination such as duration or temperature.

Klose et al. (2009) found an increase in all free amino acids in oats after malting. In lupins, the amount of all essential AA was lower after 4 days of germination $\left(\mathrm{g} \mathrm{kg}_{\text {protein }}{ }^{-1}\right)$. Due to a higher amount of crude protein (CP), some AA (Thr, Arg, His, Val, Ile, Leu, Phe) were found in higher quantities after germination $\left(\mathrm{g} \mathrm{kg} \mathrm{DM}^{-1}\right)$. Standardised ileal digestibility of methionine and lysine in pigs was lower for germinated as compared to raw lupin seeds (Chilomer et al. 2013). Khalil and Mansour (1995) found no influence of germination on the content of essential AA in faba beans, but in vitro protein digestibility was reported to be higher in germinated faba beans (Khalil and Mansour 1995, Alonso et al. 2000).

The optimal length of germination seems to be the result of a trade-off between reduction of ANF and loss of nutrients due to respiration. After germinating peas for 3 days, daily intake and utilisation of protein by rats were significantly higher when compared to raw peas, the highest reduction of ANF was reached after 6 days of germination (Vidal-Valverde et al. 2002; Ayet et al. 1997). After 6 days, however, feed intake decreased (Urbano et al. 2005a, b) and highest mobilisation of protein by hydrolysis was found after 3 days of germination (Goyoaga et al. 2011). In this study, the length of germination was 4 days, as predetermined by the device we used.

To our knowledge, no studies have been published on the potential of fresh sprouts as a feedstuff for young growing pigs in diets fed on organic farms. In this study, we tested the effects of feeding sprouts of faba bean, germinated on-farm, on production parameters of organic weaner pigs.

\section{Animals, materials and methods}

The study was conducted at the Institute of Organic Farming and Farm Animal Biodiversity (part of the Agricultural Research and Education Center) in Wels (Austria). The overall experiment consisted of four consecutive runs, each of these lasting for 4 weeks. The feeding trial complied with the rules of the EU Directive 2010/63/EU on the protection of animals used for scientific purposes (The European Parliament and the Council of the European Union 2010) and the Austrian Act on Animal Experiments. No invasive procedures were performed on the piglets.

\section{Experimental design and animals}

In total, 160 weaner piglets ([Landrace $\times$ Large White $\times[$ Pietrain $]$ ) were selected and assigned to one of the four treatments considering litter (sow), sex and bodyweight, resulting in a group size of 10 in each of the four replicates. The treatment groups were allocated to the pens following a $4 \times 4$ Latin square with balanced 
block design. The allocation of the treatments changed with every replicate, ensuring that each ration was fed once in each pen.

The animals were weaned at an age of $44.4 \pm 6$ days (mean \pm standard deviation), weighed $12.5 \pm 2 \mathrm{~kg}$ and remained in the experiment for 28 days (day 1 to day 29). Only animals without clinical signs of illness were selected to participate, one pig died during the first week of the first experimental round. Whenever pigs displayed signs of watery faeces or a soiled anal region, they were subjected to an anti-bacterial medication (Baytrilß). During the trial, the piglets were housed in pens of $5 \times 1.7 \mathrm{~m}$ which were equipped with a heated creep area, an outdoor run $(3 \times 1.7 \mathrm{~m})$, a feed trough $(2.2 \mathrm{~m})$ and two drinkers (located in the pen and outside run). All 160 pigs were habituated to the taste of sprouts by providing each litter with $0.5 \mathrm{~kg}$ germinated faba beans 3 days prior to day 1 of the experiment.

\section{Feeding regimen}

We designed four treatments: One control group with $19 \%$ pea as the main domestic protein-rich feed component and three experimental groups containing $16 \%$ raw faba bean (RFB16), $16 \%$ germinated faba bean (GFB16) and $24 \%$ of germinated faba bean (GFB24). The second main source of protein in all rations was soybean cake. The rations (see Table 1) were calculated using the software EvaPig® (version 1.3.1.7.). Nutrient contents for all components, excluding faba bean, soybean cake and oat flakes, were adopted from the INRA database implemented in the software. Values of soybean cake were adoped from Baldinger et al. (2016a) and oat flakes from DLG (2014). The treatments containing germinated faba beans were calculated based on the analysis of the nutrient profile of raw faba beans. All diets were formulated to have the same lysin content and to be iso-energetic, if possible. In $19 \%$ peas (RP19), RFB16 and GFB16, the same proportion of soybean cake was used (17\%), while in GFB24, its share was reduced to $9 \%$, resulting in slightly lower levels of $\mathrm{CP}$, lysine and methionine. The amount of all other components of treatments RFB16, GFB16 and GFB24 were the same. In RP19, the share of wheat, oats and sunflower oil was adjusted in order to achieve the same level of lysin and ME (Table 1). The faba beans used in the experiment were of the coloured variety JULIA (Table 2). The device used for germination ("Keimrad 100"®, Söllradl GmbH, 4550 Kremsmünster, Austria) consisted of a rotating cylinder made of stainless steel with four separate and perforated chambers which could be opened and closed individually. Each day, fresh sprouts were removed from one of the four chambers and the chamber filled with a defined amount of ungerminated beans (max. $8 \mathrm{~kg}$ raw seeds per chamber and day). This method implied a germination period of $96 \mathrm{~h}$. The sprouts were automatically watered for $20 \mathrm{~s}$, left for soaking for $1 \mathrm{~h}$ and for ventilation for another $3 \mathrm{~h}$, resulting in one full rotation over $4 \mathrm{~h}$. Room temperature was maintained at $16.4 \pm 1.4{ }^{\circ} \mathrm{C}$. All rations were fed five times a day as pelleted compound feed. Feed allowance was quantitatively restricted and increased slightly over the experimental period, using an automated feeding system. The daily amount of fresh germinated beans (GFB16, GFB24) was fed once a day in the morning. Before weaning, all piglets were offered ad libitum access to a commercial organic piglet starter (nutrient contents in $\mathrm{g} \mathrm{kg}^{-1}: 206.6 \mathrm{RP}, 35.3$ ether extracts, 6.9 lysine, 6.9 calcium, 2.2 phosphorus). In the first 4 days after weaning, the amount of feed was restricted to $80 \%$ of the total allowance to prevent diarrhoea.

\section{Data collection and analytical procedures}

After the initial restriction, the amount of feed was adjusted daily in a way that ensured that all of the feed was consumed by the piglets and no residuals were left in the trough. Possible leftovers were weighed and subtracted from the total amount that had been fed. If a treatment group left no feed at all, its feed allowance was increased. All animals were weighed individually prior to the first feeding on days 1, 8, 15, 22 and 29.

Raw and germinated faba beans were analysed for nutrient contents $(n=1)$. Pooled samples of each diet were taken from feed bags at the beginning and end of the experiment $(n=2)$. The samples of compound feed and faba beans were analysed at the Feed laboratory of the Provincial Chamber of Agriculture of Lower Austria, 3250 Wieselburg-Land, Austria, according to the German Handbook of Agricultural Experimental and Analytical Methods (VDLUFA 2007; method number in brackets). The dry matter content of feed was determined by ovendrying at $105{ }^{\circ} \mathrm{C}$ (3.1); crude protein was analysed by Dumas combustion (4.1.2). Contents of metabolizable energy (ME) were calculated according to GfE (2008).

Samples of raw and germinated faba beans were analysed for their amino acid profile at the Department of Chemistry, Division of Biochemistry at BOKUUniversity of Natural Resources and Life Sciences 
Table 1 Composition and calculated nutrient and energy contents of the experimental diets

\begin{tabular}{|c|c|c|c|c|}
\hline & \multicolumn{4}{|l|}{ Diets } \\
\hline & RP19 & RFB16 & GFB16 & GFB24 \\
\hline \multicolumn{5}{|l|}{ Composition } \\
\hline Faba beans, raw & - & 160 & - & - \\
\hline Faba beans, germinated & - & - & 160 & 240 \\
\hline Peas & 190 & - & - & - \\
\hline Soybean cake & 170 & 170 & 170 & 90 \\
\hline Wheat & 200 & 235 & 235 & 235 \\
\hline Barley & 260 & 250 & 250 & 250 \\
\hline Sunflower oil & 15 & 20 & 20 & 20 \\
\hline Skimmed milk powder & 30 & 30 & 30 & 30 \\
\hline Wheat bran & 50 & 50 & 50 & 50 \\
\hline Oat flakes & 60 & 60 & 60 & 60 \\
\hline Mineral and vitamin premix & 25 & 25 & 25 & 25 \\
\hline \multicolumn{5}{|l|}{ Nutrients and energy } \\
\hline Crude protein $\left(\mathrm{g} \mathrm{kg}^{-1}\right)$ & 183 & 190 & 190 & 178 \\
\hline $\operatorname{ME}\left(\mathrm{MJ} \mathrm{kg}^{-1}\right)^{\mathrm{a}}$ & 13.25 & 13.24 & 13.24 & 13.08 \\
\hline Lysine $\left(\mathrm{g} \mathrm{kg}^{-1}\right)$ & 10.2 & 10.3 & 10.3 & 9.7 \\
\hline g Lys MJ ME ${ }^{-1}$ & 0.77 & 0.78 & 0.78 & 0.74 \\
\hline Cysteine $\left(\mathrm{g} \mathrm{kg}^{-1}\right)$ & 3.2 & 3.3 & 3.3 & 3 \\
\hline Methionine $\left(\mathrm{g} \mathrm{kg}^{-1}\right)$ & 2.7 & 2.7 & 2.7 & 2.4 \\
\hline Methionine + cysteine $\left(\mathrm{g} \mathrm{kg}^{-1}\right)$ & 5.9 & 6 & 6 & 5.4 \\
\hline Threonine $\left(\mathrm{g} \mathrm{kg}^{-1}\right)$ & 6.8 & 6.9 & 6.9 & 6.4 \\
\hline Tryptophan $\left(\mathrm{g} \mathrm{kg}^{-1}\right)$ & 2.2 & 2.2 & 2.2 & 2 \\
\hline
\end{tabular}

RP19 control diet, RFB16 16\% raw faba bean, GFB16 16\% germinated faba bean, GFB24 24\% germinated faba bean

${ }^{a}$ Metabolizable energy content calculated according to GfE (2008)

Vienna with a high-performance liquid chromatographic (HPLC) system (Hewlett Packard 1050) and a variable wavelength fluorescence detector (Shimandzu RF 535). After freeze-drying and milling of germinated faba beans, the samples were subjected to hydrolysis for $20 \mathrm{~h}$ in $6 \mathrm{M} \mathrm{HCl}$. The samples were oxidised to prevent losses of methionine and cysteine; tryptophan was stabilised with alkaline $\mathrm{Ba}(\mathrm{OH})_{2}$.

\section{Statistical analysis}

Statistical analysis of data was conducted with SAS 9.4 (SAS Institute Inc.).

Body weight was measured on individual piglets at multiple time points, and the parameters "body weight" and "daily weight gain" therefore were treated as repeated measurements. The interval between measurements was 7 days (days 1, 8, 15, 22, 29) in the replicates one, two and three. In replicate four, piglets were weighed on day 14 instead of day 15 . This unbalanced measurement was corrected for by addition of one average daily body weight gain between days 15 and 22 .

To consider the random effect of the individual piglet, body weight and daily weight gain were analysed using the procedure MIXED. Because of the Bayesian information criterion (BIC) being closer to zero, differences of correlations within repeated measurements on one individual piglet were accounted for using statement repeated.

Four suitable covariance structures were tested (Toeplitz, autoregressive (1), unstructured, variance components), of which Toeplitz was chosen because of the BIC being closest to zero. Multiple comparison of means were conducted using the Tukey-Kramer test and statistical differences interpreted as significant when $P<0.05$. 
Table 2 Nutrient contents of raw and germinated faba bean seeds ( $\mathrm{g} \mathrm{kg} \mathrm{DM}{ }^{-1}$ unless stated otherwise) $(n=1)$

\begin{tabular}{|c|c|c|c|}
\hline & $\begin{array}{l}\text { Faba bean, } \\
\text { raw }\end{array}$ & $\begin{array}{l}\text { Faba bean, } \\
\text { germinated }\end{array}$ & $\begin{array}{l}\text { Difference } \\
(\%)\end{array}$ \\
\hline Energy (MJ ME) & 14.52 & 14.48 & -0.3 \\
\hline Crude fibre & 81 & 85 & +5.0 \\
\hline Ether extracts & 15 & 15 & - \\
\hline $\mathrm{N}$-free extracts & 550 & 542 & -1.5 \\
\hline Crude protein & 317 & 321 & +1.0 \\
\hline Lysine $^{a}$ & 7.82 & 7.70 & -1.5 \\
\hline Methionine $^{\mathrm{a}}$ & 1.00 & 0.98 & -2.0 \\
\hline Cysteine $^{a}$ & 1.64 & 1.62 & -1.2 \\
\hline $\begin{array}{c}\text { Methionine + } \\
\text { cysteine }^{\mathrm{a}}\end{array}$ & 2.64 & 2.57 & -2.7 \\
\hline Tryptophan ${ }^{\mathrm{a}}$ & 1.02 & 1.05 & +2.9 \\
\hline Threonine $^{\mathrm{a}}$ & 3.85 & 3.84 & -0.3 \\
\hline Serin $^{\mathrm{a}}$ & 4.59 & 4.74 & +3.3 \\
\hline Histidin $^{\mathrm{a}}$ & 2.76 & 2.81 & +1.8 \\
\hline Glycine $^{\mathrm{a}}$ & 4.46 & 4.36 & -2.2 \\
\hline Arginine $^{a}$ & 11.21 & 11.11 & -0.9 \\
\hline Alanine $^{\mathrm{a}}$ & 4.65 & 5.16 & +11.0 \\
\hline Tyrosine $^{a}$ & 3.31 & 3.23 & -2.4 \\
\hline Valine $^{a}$ & 5.10 & 5.08 & -0.4 \\
\hline Isoleucine $^{\mathrm{a}}$ & 4.59 & 4.54 & -1.1 \\
\hline Phenylalanine $^{\mathrm{a}}$ & 4.81 & 4.83 & +0.4 \\
\hline Leucine $^{\mathrm{a}}$ & 8.8 & 8.74 & -0.7 \\
\hline Aspartic acid ${ }^{\mathrm{a}}$ & 11.58 & 11.21 & -3.2 \\
\hline Glutamic acid $^{\mathrm{a}}$ & 18.80 & 18.99 & +1.0 \\
\hline $\begin{array}{l}\text { Lys/Met + Cys/ } \\
\text { Thr/Tr }\end{array}$ & 1:0.3:0.5:0.13 & 1:0.3:0.5:0.14 & \\
\hline
\end{tabular}

${ }^{\mathrm{a}}$ Amount of AA in percentage of hydrolysed protein

Daily feed intake $\left(\mathrm{g} \mathrm{day}^{-1}\right.$ piglet $\left.^{-1}\right)$ and feed conversion ratio ( $\mathrm{kg}$ feed intake $\mathrm{kg}^{-1}$ weight gain) were analysed on group level using procedure GLM. The effect of sex was not significant in any of the two models and was therefore removed from the model. The following models were used for analysis:

Body weight and daily weight gain

$$
\begin{aligned}
Y_{\text {klmnop }}= & \mu+\operatorname{diet}_{k}+\operatorname{pen}_{l}+\text { replicate }_{m} \\
& +\operatorname{sow}_{n}\left(\text { replicate }_{m}\right)+\operatorname{day}_{o}+\operatorname{day}_{o} \times \operatorname{diet}_{k} \\
& +\operatorname{piglet}_{p}\left(\operatorname{diet}_{k}\right)+b_{1} \times \text { bw_weaning } \\
& +\varepsilon_{\text {klmnopq }}
\end{aligned}
$$

Feed intake and feed conversion ratio

$$
\begin{aligned}
Y_{k l m}= & \mu+\operatorname{diet}_{k}+\operatorname{pen}_{l}+\text { replicate }_{m}+b_{2} \times \text { day }+\mathrm{b}_{3} \\
& \times \text { day }^{2}+\varepsilon_{k l m}
\end{aligned}
$$

Legend:

$Y=$ variable studied; $\mu=$ intercept diet $_{k}=$ fixed effect of $\operatorname{diet}(k=\mathrm{RP} 19, \mathrm{CG}, \mathrm{GFB} 16, \mathrm{GFB} 24) ;$ pen $_{l}=$ fixed effect of pen $(l=1,2,3,4)$; replicate $_{m}=$ fixed effect of replicate $(m=1,2,3,4) ; \operatorname{sow}_{n}\left(\right.$ replicate $\left._{m}\right)=$ fixed effect of sow ( $n=$ number of ear tag) within replicate; day $_{o}=$ fixed effect of day $(o=8,15,22,29)$, day $_{o} \times \operatorname{diet}_{k}=$ interaction between day and diet; $\operatorname{piglet}_{p}\left(\operatorname{diet}_{k}\right)=$ random effect of piglet ( $p=$ number of ear tag) within diet; bw_weaning $=$ continuous effect of body weight at weaning; day = continuous effect of day; day $^{2}=$ quadratic effect of day; $b_{1}=$ regression coefficient of body weight at weaning; $b_{2}=$ regression coefficient of day; $b_{3}$ $=$ regression coefficient of quadratic effect of day; $\varepsilon=$ random error.

\section{Results and discussion}

In this study we tested the effects of germinating faba beans ( $V$. faba L.) in a ration for weaner pigs on the parameters feed intake, body weight, daily weight gain and feed conversion ratio. Results from literature suggest that germination can increase digestibility of protein and the content of essential amino acids (Khalil and Mansour 1995; G Urbano et al. 2005a, b; Ghavidel and Prakash 2007; Gulewicz et al. 2014).

After 4 days of germination, the content of crude protein slightly increased from $317 \mathrm{~g} \mathrm{~kg} \mathrm{DM}^{-1}$ in raw beans to $321 \mathrm{~g} \mathrm{~kg} \mathrm{DM}^{-1}$ in sprouts $(n=1)$. This small increase $(+1 \%)$ might be related to the decline in $\mathrm{N}$-free extracts $(-1.5 \%)$ due to degradation of carbohydrates during germination (Donangelo et al. 1995; Chilomer et al. 2013). The fraction of carbohydrates in faba beans is smaller than in cereals such as wheat. This could explain the greater increase in CP found for wheat after 5 days of germination, since respiration leads to a loss of carbohydrates in the range of 5-8\% of dry matter (Seggin et al. 2003). Also, starch is metabolised more quickly and used for germination earlier than the crude fibre (CF) fraction, resulting in an increased amount of $\mathrm{CF}(+5 \%)$ in sprouts (Table 2$)$. 
Although the total amount of amino acids in $\mathrm{g} \mathrm{kg} \mathrm{DM}{ }^{-1}$ increased after germination due to the increase in crude protein, the proportion of all essential amino acids (except tryptophan) in the total amount of hydrolysed protein decreased by $1.2 \%$ (cysteine) to $2 \%$ (methionine). These results correspond to those reported by Chilomer et al. (2013) who found that germination decreased the content of all essential amino acids in lupins, but not to those from Luo et al. (2014) who found that lysine content increased after germination of green faba beans (but not of white faba beans). Since there was only one sample of raw and germinated beans analysed, no information is available on the potential variability of nutrient contents of the faba beans used in this experiment.

A considerable amount of the studies on germination as a method to increase the nutrional value of raw seeds were conducted for human nutrion. In these studies, rats were frequently used as a model; they require only relatively small quantities of germinated seeds, which can be freeze dried and milled in the laboratory before being processed together with the other ingredients of the ration. Only few studies were conducted in which sprouts were fed to pigs. Hunger (2011) studied the effects of feeding germinated wheat to weaner pigs. After germination, the sprouts were dried (90\% DM), ground and, together with the other dietary compontents, processed as pellets. Kasprowicz-Potocka et al. (2013) also dried (90\% DM) and ground sprouts of germinated lupins before feeding them to weaner pigs. Both studies used synthetic amino acids to supplement the rations, which was not done in the current study because of the ban of synthetic amino acids in diets of organic livestock (EU 2008).

In this experiment, a defined amount of fresh sprouts was fed once daily in the morning. The animals consumed their daily amount of germinated faba beans within a few hours. As the other components were fed in pelleted form and in five meals over the course of 1 day, the animals probably consumed a protein-rich portion of their diet, not ideally balanced for AA, at the beginning of each day, which might have influenced the piglets' performance (Boisen et al. 2000; Kim et al. 2012).

Contrary to the hypothesis that the physiological processes which occur during germination may lead to a higher feeding value and cause an improved animal performace, results for body weight and daily weight gain of treatment groups containing sprouts were mostly lower than those of RP19 amd RFB16 (Table 3). The interaction between day and treatment was significant for body weight $(P<0.01)$ and daily weight gain $(P<0.01)$, as the reduced growth of pigs in treatments GFB16 and GFB24 occurred in weeks 3 and 4 of the trial, while in the first 2 weeks, no clear trend was recorded.

There were no statistically significant differences in the live weight of the animals on days $1,8,15$ and 22 (Table 3). Despite not reaching significance, the lower body weight of treatments fed germinated beans was already observable on day 22 . On day 29 , body weight of GFB24 pigs was significantly lower than that of RP19 and RFB16, while GFB16 did not differ significantly from either treatment. Accordingly, while there were no significant differences in the daily weight gain of RP19, RFB16 and GFB16 in week 4, weight gain of GFB24 was significantly lower than in the other groups.

Overall, the performance in this trial was similar to two previous studies using the same control group and feeding technology for studies on sainfoin (Baldinger et al. 2016a) and grass pea (Baldinger et al. 2016b) as a home-grown source of protein for weaner pigs. Mean daily weight gain in the sainfoin study was in the range of 292 to $395 \mathrm{~g} \mathrm{day}^{-1}$ and of 403 to $412 \mathrm{~g} \mathrm{day}^{-1}$ in the grasspea study. Despite higher feed intake, mean daily weight gain of RP19 (391 $\mathrm{g} \mathrm{day}^{-1}$ ) was slightly lower than in the control group of the grasspea study $\left(412 \mathrm{~g} \mathrm{day}^{-1}\right)$, but about the same as in the sainfoin study (395 $\mathrm{g} \mathrm{day}^{-1}$ ).

No analysis of ANF was performed in this study; therefore, the discussion of potential effects of germination is limited to an examination of the performance parameters. Since performance of RFB16, containing ungerminated faba beans, was better than both of the experimental groups with germinated beans as well as the control group containing peas, it seems reasonable to assume that ANF did not substantially influence the availability of nutrients and the performance of the animals (Rubio et al. 2002). Consequently, there were no visible effects of a potential reduction of ANF due to germination (Alonso et al. 2000; Gulewicz et al. 2014).

The crude protein and energy contents of the rations were about $1.6 \pm 0.43 \mathrm{~g} \mathrm{~kg} \mathrm{DM}^{-1}$ lower and $0.6 \mathrm{MJ} \mathrm{ME} \mathrm{kg} \mathrm{DM}^{-1}$ higher, respectively, than planned. To calculate the intake of RP, ME and AA, this deviation was accounted for in the calculation of amino acid contents of the different rations. 
Table 3 Body weight and daily weight gain of piglets fed organic diets with and without germinated faba beans

\begin{tabular}{|c|c|c|c|c|c|c|c|c|c|}
\hline \multirow[t]{2}{*}{ Trait } & \multirow[t]{2}{*}{ Days } & \multicolumn{4}{|l|}{ Diets } & \multicolumn{4}{|c|}{$P$ values } \\
\hline & & RP19 & RFB16 & GFB16 & GFB24 & Diet & Pen & Replicate & Day \\
\hline \multirow[t]{6}{*}{ Body weight $(\mathrm{kg})^{\mathrm{a}}$} & 1 & 12.5 & 12.5 & 12.5 & 12.5 & & & & \\
\hline & 8 & 13.3 & 13.3 & 13.3 & 13.2 & & & & \\
\hline & 15 & 16.0 & 15.8 & 15.9 & 15.6 & & & & \\
\hline & 22 & 19.2 & 19.1 & 18.8 & 18.6 & & & & \\
\hline & 29 & $23.5 \mathrm{a}$ & $23.8 \mathrm{a}$ & $23.0 \mathrm{ab}$ & $22.2 b$ & & & & \\
\hline & SEM & 0.25 & 0.25 & 0.25 & 0.25 & $0.180^{\mathrm{a}}$ & 0.093 & $<0.001$ & $<0.001$ \\
\hline \multirow[t]{6}{*}{ Daily weight gain $(g)^{a}$} & $1-8$ & 124 & 115 & 120 & 122 & & & & \\
\hline & $9-15$ & 375 & 355 & 374 & 333 & & & & \\
\hline & $16-22$ & 455 & 472 & 408 & 421 & & & & \\
\hline & $23-29$ & $608 \mathrm{a}$ & $660 \mathrm{a}$ & $601 \mathrm{a}$ & $499 b$ & & & & \\
\hline & Overall & $391 \mathrm{a}$ & $401 \mathrm{a}$ & $376 a b$ & $344 \mathrm{~b}$ & & & & \\
\hline & SEM & 19.5 & 19.3 & 19.2 & 19.4 & $0.001^{\mathrm{a}}$ & 0.02 & $<0.001$ & $<0.001$ \\
\hline
\end{tabular}

The table shows least-square estimates and $P$ values of the effect of diet. In addition, least-square estimates for individual time periods are given for further illustration. $P$ values $<0.05$ are considered to indicate significant differences and are in italics. Entries followed by different lowercase letters are significantly different

RP19 control diet, RFB16 16\% raw faba beans, GFB16 16\% germinated faba beans, GFB24 $24 \%$ germinated faba beans.

${ }^{\mathrm{a}} P$ values of sow(replicate) and bw_weaning $<0.001$

Table 4 Feed intake and FCR of piglets fed organic diets with and without germinated faba beans

\begin{tabular}{|c|c|c|c|c|c|c|c|c|c|c|}
\hline \multirow[t]{2}{*}{ Trait } & \multirow[t]{2}{*}{ Days } & \multicolumn{4}{|l|}{ Diets } & \multirow[t]{2}{*}{ SEM } & \multicolumn{4}{|c|}{$P$ values } \\
\hline & & RP19 & RFB16 & GFB16 & GFB24 & & Diet & Pen & Replicate & Day \\
\hline \multirow[t]{5}{*}{ Feed intake $\left(\mathrm{g} \mathrm{day}^{-1}\right)$} & $1-8$ & 301 & 294 & 309 & 292 & 20.2 & & & & \\
\hline & $9-15$ & 557 & 550 & 565 & 548 & 17.7 & & & & \\
\hline & $16-22$ & 869 & 862 & 876 & 859 & 17.7 & & & & \\
\hline & $23-29$ & 1236 & 1229 & 1244 & 1227 & 20.2 & & & & \\
\hline & Overall & 741 & 734 & 748 & 731 & 15.5 & 0.865 & 0.006 & 0.456 & $<0.001^{\mathrm{a}}$ \\
\hline \multirow[t]{5}{*}{ Feed Conversion Ratio $\left(\mathrm{kg} \mathrm{LW}^{-1}\right)$} & $1-8$ & 2.37 & 2.31 & 2.47 & 2.51 & 0.15 & & & & \\
\hline & $9-15$ & 1.75 & 1.69 & 1.85 & 1.89 & 0.14 & & & & \\
\hline & $16-22$ & 1.68 & 1.62 & 1.79 & 1.82 & 0.14 & & & & \\
\hline & $23-29$ & 2.17 & 2.10 & 2.27 & 2.30 & 0.15 & & & & \\
\hline & Overall & 1.99 & 1.93 & 2.10 & 2.13 & 0.12 & 0.614 & 0.7 & 0.161 & $<0.001^{\mathrm{a}}$ \\
\hline ME intake $\left(\mathrm{MJ} \mathrm{day}^{-1}\right)$ & Overall & 9.95 & 9.90 & 10.03 & 9.59 & 0.21 & 0.466 & 0.007 & 0.448 & $<0.001^{\mathrm{a}}$ \\
\hline $\mathrm{CP}$ intake $\left(\mathrm{g} \mathrm{day}^{-1}\right)$ & Overall & 124.51 & 127.62 & 131.76 & 124.73 & 2.71 & 0.211 & 0.007 & 0.47 & $<0.001^{\mathrm{a}}$ \\
\hline Lysine intake $\left(\mathrm{g} \mathrm{day}^{-1}\right)$ & Overall & 6.98 & 6.92 & 7.18 & 6.83 & 0.15 & 0.381 & 0.006 & 0.462 & $<0.001^{\mathrm{a}}$ \\
\hline Methionine intake $\left(\mathrm{g} \mathrm{day}^{-1}\right)$ & Overall & $1.83 \mathrm{a}$ & $1.83 \mathrm{a}$ & $1.91 \mathrm{a}$ & $1.67 \mathrm{~b}$ & 0.04 & 0.001 & 0.01 & 0.467 & $<0.001^{\mathrm{a}}$ \\
\hline
\end{tabular}

The table shows least-square estimates and $P$ values of the effect of diet. In addition, least-square estimates for individual time periods are given for further illustration. $P$ values $<0.05$ are considered to indicate significant differences and are in italics. Entries followed by different lowercase letters are significantly different

$R P 19$ control diet, $R F B 16,16 \%$ raw faba beans, GFB16 16\% germinated faba beans, GFB24 $24 \%$ germinated faba beans

${ }^{\text {a }} P$ value of day $\times$ day $<0.001$ 
According to Kasprowicz-Potocka et al. (2013), germination of lupin reduces feed palatability and feed intake and Bau et al. (2000) advise that, to ensure nutritive quality, due to possible microbial contamination or oxydation of lipids, sprouts of soybeans should be heated before consumption if germination lasts longer than 3 days. Still, increased palatability is often mentioned as a benefit of germination (Urbano et al. 2005a, b; Luo et al. 2014; Mäkinen and Arendt 2015). Our data on feed intake do not confirm this hypothesis. When feeding $24 \%$ ungerminated faba beans to weaner pigs, a decrease in feed intake was found (Partanen et al. 2006). In this study, the treatment group GFB24 (24\% germinated beans) showed the lowest mean feed intake (731 $\mathrm{g} \mathrm{DM} \mathrm{day}^{-1}$ ), but differed only negligibly (17 $\mathrm{g} \mathrm{DM} \mathrm{day}^{-1}$ ) from GFB16, the group with the highest feed intake. Consequently, no significant differences were found for the feed intake between treatments (Table 4).

Feed was not offered ad libitum to the animals, instead the daily amount of feed offered was based on the leftovers collected from the trough. In this case, differences in feed intake might be less pronouced than when fed ad libitum, but should still be visible.

Intake of methionine was significantly lower in GFB24 than in all other treatments. This was due to the lower level of methionine in the diet, which could not be compensated for by germination. The lower body weight and daily weight gain of GFB16 as compared to RFB16 might indicate that digestibility of methionine and lysine could have been lower after germination (Tables 1 and 4).

There were no significant differences in the feed conversion ratio of the four treatments. Feed conversion of RFB16 was numerically consistently better than that of RP19, GFB16 and GFB24. While GFB16 had the highest $\mathrm{CP}$ intake, its conversion ratio for $\mathrm{CP}$ was also the highest (data not shown).

Germination seemed to have no influence on the occurrence of diarrhoea. Treatments were recorded for $33 \%$ of animals in RP19, $40 \%$ in RFB16, 33\% in GFB16 and $30 \%$ in GFB24, which is comparable to Baldinger et al. (2016a), who noted 29-37\% of animals as having received treatments for diarrhoea.

\section{Conclusions}

Germination of raw faba beans had no positive effects on daily weight gain and body weight of organic weaner pigs. There was no significant effect of germination on total feed intake. Germinated faba beans could be fed in proportions up to $240 \mathrm{~g} \mathrm{~kg} \mathrm{diet}^{-1}$ without a decline in feed intake. Still, the lower intake of essential amino acids of GFB24 could not be compensated for by germination, resulting in a significantly lower weight gain and body weight at the end of the feeding trial. Under the circumstances of this study and considering the effort related to the process, germination cannot be recommended as a method to improve the feeding value of protein in faba beans for feeding of weaner pigs.

Acknowledgements Open access funding provided by University of Natural Resources and Life Sciences Vienna (BOKU). We want to thank Fa. Söllradl for the provision of the germination device and Johann Ollmann (Bioschwein Austria) for financially supporting the first author.

Compliance with ethical standards The feeding trial complied with the rules of the EU Directive 2010/63/EU on the protection of animals used for scientific purposes (The European Parliament and the Council of the European Union 2010) and the Austrian Act on Animal Experiments.

Open Access This article is distributed under the terms of the Creative Commons Attribution 4.0 International License (http:// creativecommons.org/licenses/by/4.0/), which permits unrestricted use, distribution, and reproduction in any medium, provided you give appropriate credit to the original author(s) and the source, provide a link to the Creative Commons license, and indicate if changes were made.

\section{References}

Ahmed FA, Abdel-Rahim EA-M, Abdel-Fatah OM, Erdmann VA, Lippmann C (1995) The changes of protein patterns during one week of germination of some legume seeds and roots. Food Chem 52:433-437

Alonso R, Aguirre A, Marzo F (2000) Effects of extrusion and traditional processing methods on antinutrients and in vitro digestibility of protein and starch in faba and kidney beans. Food Chem 68:159-165

Ayet G, Burbano C, Cuadrado C, Pedrosa MM, Robredo LM, Muzquiz M, De La Cuadra C, Castaño A, Osagie A (1997) Effect of germination, under different environmental conditions, on saponins, phytic acid and tannins in lentils (Lens culinaris). J Sci Food Agric 74:273-279

Baldinger, L, Hagmüller, W, Minihuber, U, Matzner, M, \& Zollitsch, W (2016a) Sainfoin seeds in organic diets for weaned piglets - utilizing the protein-rich grains of a longknown forage legume. Renew Agric Food Syst 31:12-21

Baldinger L, Hagmüller W, Minihuber U, Schipflinger M, Zollitsch W (2016b) Organic grass pea (Lathyrus sativus L.) seeds as a protein source for weaned piglets: effects of seed 
treatment and different inclusion rates on animal performance. Renew Agric Food Syst 31:269-279

Bau HM, Villaume C, Méjean L (2000) Effects of soybean (Glycine max) germination on biologically active components, nutritional values of seeds, and biological characteristics in rats. Die Nahrung 44:2-6

Blair R (2007) Nutrition and feeding of organic pigs. CAB International, Wallingford

Boisen S, Hvelplund T, Weisbjerg MR (2000) Ideal amino acid profiles as a basis for feed protein evaluation. Livest Prod Sci 64:239-251

Boulter D, \& Barber JTT (1963) Amino-Acid Metabolism in Germinating Seeds of Vicia Faba L . in Relation To Their Biology. New Phytol 62:301-316

Carbonaro M, Grant G, Cappelloni M, Pusztai A (2000) Perspectives into factors limiting in vivo digestion of legume proteins: Antinutritional compounds or storage proteins? J Agric Food Chem 48:742-749

Carbonaro M, Maselli P, Nucara A (2014) Structural aspects of legume proteins and nutraceutical properties. Food Res Int 76:19-30

Chaudhary R, Oluyemisi AE, Shrestha AK, Adhikari BM (2015) Effect of germination on biochemical and nutritional quality of Kwati. J Food Process Preserv 39:1509-1517

Chilomer K, Kasprowicz-Potocka M, Gulewicz P, Frankiewicz A (2013) The influence of lupin seed germination on the chemical composition and standardized ileal digestibility of protein and amino acids in pigs. J Anim Physiol Anim Nutr 97:639-646

Crépon K, Marget P, Peyronnet C, Carrouée B, Arese P, Duc G (2010) Nutritional value of faba bean (Vicia faba L.) seeds for feed and food. Field Crop Res 115:329-339

Dersjant-li Y, Peisker M (2010) The impact of soy oligosaccharides on digestion and intestinal health in weaning piglets. Livest Sci 134:187-189

DLG (2014) DLG-Futterwerttabellen Schweine, 7th edn. DLGVerlag GmbH, Frankfurt am Main

Donangelo CM, Trugo LC, Trugo NMF, Eggum BO (1995) Effect of germination of legume seeds on chemical composition and on protein and energy utilization in rats. Food Chem 53:23-27

Emiola IA, Gous RM (2011) Nutritional evaluation of dehulled faba bean (Vicia faba cv. Fiord) in feeds for weaner pigs. S Afr J Anim Sci 41:79-86

European Union (EU) (2008) Commission Regulation (EC) No $889 / 2008$ of 5 September 2008 laying down detailed rules for the implementation of Council Regulation (EC) No 834/2007 on organic production and labelling of organic products with regard to organic production, labelling and control. Official Journal of the European Union, Brussels. http://eur-lex. europa.eu/LexUriServ/LexUriServ.do?uri=OJ:L:2008:250 :0001:0084:en:PDF. Accessed 12 September 2017

Fernandez ML, Berry JW (1989) The effect of germination on chickpea starch. Starch/Stärke 41:17-21

Frias J, Miranda ML, Doblado R, Vidal-Valverde C (2005) Effect of germination and fermentation on the antioxidant vitamin content and antioxidant capacity of Lupinus albus L. var. Multolupa. Food Chem 92:211-220

Früh B, Schlatter B, Isensee A, Maurer V, Willer H (2015) Report on organic protein availability and demand in Europe. Research Institute of Organic Agriculture (FiBL), Frick

GfE-Society of Nutrition Physiology (2008). Prediction of metabolisable energy of compound feeds for pigs.
Proceedings of the Society of Nutrition Physiology 17: 199-204

Ghavidel RA, Prakash J (2007) The impact of germination and dehulling on nutrients, antinutrients, in vitro iron and calcium bioavailability and in vitro starch and protein digestibility of some legume seeds. LWT Food Sci Technol 40:1292-1299

Goyoaga C, Burbano C, Cuadrado C, Romero C, Guillamón E, Varela A, Pedrosa MM, Muzquiz M (2011) Content and distribution of protein, sugars and inositol phosphates during the germination and seedling growth of two cultivars of Vicia faba. J Food Compos Anal 24:391-397

Gulewicz P, Martinez-Villaluenga C, Kasprowicz-Potocka M, Frias J (2014) Non-nutritive compounds in Fabaceae family seeds and the improvement of their nutritional quality by traditional processing - a review. Polish J Food Nutri Sci 64:75-89

Hunger A (2011) Ernährungsphysiologische Untersuchungen zur Wirkung von gekeimtem Weizen bei Absetzferkeln. 1st ed. VVB Laufersweiler, Gießen, Germany

Jeroch H, Drochner W, Simon O (2008) Ernährung landwirtschaftlicher Nutztiere: Ernährungsphysiologie, Futtermittelkunde, Fütterung. 2nd ed. UTB, Eugen Ulmer KG, Stuttgart (Hohenheim), Germany

Kasprowicz-Potocka M, Chilomer K, Zaworska A, Nowak W, Frankiewicz A (2013) The effect of feeding raw and germinated Lupinus luteus and Lupinus angustifolius seeds on the growth performance of young pigs. J Anim Feed Sci 22:116-121

Kaukovirta-Norja A, Wilhelmson A, Poutanen K (2004) Germination: a means to improve the functionality of oat. Agric Food Sci 13:100-112

Khalil AH, Mansour EH (1995) The effect of cooking, autoclaving and germination on the nutritional quality of faba beans. Food Chem 54:177-182

Kim JC, Hansen CF, Mullan BP, Pluske JR (2012) Nutrition and pathology of weaner pigs: nutritional strategies to support barrier function in the gastrointestinal tract. Anim Feed Sci Technol 173:3-16

Klose C, Schehl BD, Arendt EK (2009) Fundamental study on protein changes taking place during malting of oats. J Cereal Sci 49:83-91

Luo, Y, Jin, X, Hao, Z, Wang, Q, Zhu, L, \& He, Y (2014) Effect of sprouting on amino acids, protein solubility and availability in green and white faba bean (Vicia faba L). Adv J Food Sci Technol 6: 531-536

Mäkinen OE, Arendt EK (2015) Nonbrewing applications of malted cereals, pseudocereals, and legumes: a review. J Am Soc Brew Chem 73:223-227 Available from: http://www. scopus.com/inward/record.url?eid=2-s2.0-84938914206 \&partnerID=tZOtx3y1

Makkar HPS, Becker K, Abel H, Pawelzik E (1997) Nutrient contents, rumen protein degradability and antinutritional factors in some colour- and white-flowering cultivars of Vicia faba beans. J Sci Food Agric 75:511-520

Partanen K, Siljander-rasi H, Alaviuhkola T (2006) Feeding weaned piglets and growing-finishing pigs with diets based on mainly home-grown organic feedstuffs. Agric Food Sci 15:89-105

Peer DJ, Leeson S (1985) Feeding value of hydroponically sprouted barley for poultry and pigs. Anim Feed Sci Technol 13:183-190

Rubio LA (2007) Carbohydrates digestibility and faecal nitrogen excretion in rats fed raw or germinated faba bean (Vicia faba)- and chickpea (Cicer arietinum)-based diets. Br J Nutr 90:301 
Rubio, L A, Muzquiz, M, Burbano, C, Cuadrado, C, \& Pedrosa, M M (2002) High apparent ileal digestibility of amino acids in raw and germinated faba bean (Vicia faba)- and chickpea (Cicer arietinum)-based diets for rats. J Sci Food Agric 82: 1710-1717

Sarwar Gilani G, Wu Xiao C, Cockell KA (2012) Impact of antinutritional factors in food proteins on the digestibility of protein and the bioavailability of amino acids and on protein quality. Br J Nutr 108:315-332

Seggin, S, Jansen, G, Kurpjun, C, Jürgens, H-U, \& Flamme, W (2003) Gekeimte Samen als Futtermittel-Analytik. Bundesanstalt für Züchtungsforschung an Kulturpflanzen Abschlussbericht zum Forschungsprojekt (02OE662) Gekeimte Samen als Futtermittel-Analytik. BÖLBundesprogramm Ökologischer Landbau

The European Parliament and the Council of the European Union (2010) Directive 2010/63/EU of 22 September 2010 on the protection of animals used for scientific purposes. Off J Eur Union 276:33-79

Urbano G, Aranda P, Vilchez A, Aranda C, Cabrera L, Porres J, Lopezjurado M (2005a) Effects of germination on the composition and nutritive value of proteins in Pisum sativum. $\mathrm{L}$ Food Chem 93:671-679
Urbano G, López-Jurado M, Frejnagel S, Gómez-Villalva E, Porres JM, Frías J, Vidal-Valverde C, Aranda P (2005b) Nutritional assessment of raw and germinated pea (Pisum sativum L.) protein and carbohydrate by in vitro and in vivo techniques. Nutrition 21:230-239

VDLUFA[Association of German Agricultural Analytic and Research Institutes] (2007) Handbuch der Landwirtschaftlichen Versuchsund Untersuchungsmethodik, Band III: Die chemische Untersuchung von Futtermitteln [Handbook of Agricultural Experimental and Analytical Methods, Volume III: The Chemical Analysis of Feeds.] 3rd ed. VDLUFA-Verlag, Darmstadt, Germany

Vidal-Valverde C, Frias J, Sierra I, Blazquez I, Lambein F, Kuo Y$\mathrm{H}$ (2002) New functional legume foods by germination: effect on the nutritive value of beans, lentils and peas. Eur Food Res Technol 215:472-477

Zijlstra RT, Lopetinsky K, Beltranena E (2008) The nutritional value of zero-tannin faba bean for grower-finisher pigs. Can J Anim Sci 88:293-302

Zollitsch W (2007) Challenges in the nutrition of organic pigs. J Sci Food Agric 87:2747-2750

Zollitsch W, Wagner E, Wlcek S (2002) Ökologische Schweine/ Geflügel-Fütterung, 1. Auflage edn. Österreichischer Agrarverlag, Leopoldsdorf 